\title{
OPTIMALISASI PROSES ASESMEN TERHADAP PENYALAH GUNA NARKOTIKA DALAM RANGKA EFEKTIVITAS REHABILITASI MEDIS DAN SOSIAL BAGI PECANDU NARKOTIKA
}

\section{(Optimizing Assessment Process to Drug User Within the Scope of Effective Medical and Social Rehabilitation for Drug Addicts)}

\author{
Riki Afrizal, Upita Anggunsuri \\ Fakultas Hukum Universitas Andalas, Padang \\ Kampus Limau Manis Padang, Sumatera Barat \\ HP. 081374824746 \\ rikifhunand@gmail.com, upitaanggun@gmail.com
}

Tulisan Diterima: 19 November 2018; Direvisi: 1 Maret 2019; Disetujui Diterbitkan 10 September 2019

DOI: http://dx.doi.org/10.30641/dejure.2019.V19.259-268

\begin{abstract}
Article 54 of the Law No. 35 of 2009 regarding Narcotics provides for that drug addicts and victims of drug abuse must undergo medical and social rehabilitations. Further, Article 127 clause (3) of the Law provides for that in the cases where the addict has been proved or evidenced to be a victim of drug abuse, the addict must undergo medical rehabilitation and social rehabilitation. The regulation brings opportunities for the people who are being involved in any legal proceedings related to narcotics to apply for the medical rehabilitation and social rehabilitation procedures. Whether their applications will be approved or not will depend on the assessment. This assessment plays an important role in determining whether a drug addict may be admitted to the rehabilitation processes or not. This research discusses the issues on: 1) the assessment processes of the drug addicts during the investigation and prosecution stages, 2) how to coordinate the investigators and public prosecutors with the medical rehabilitation and social rehabilitation institutions. The method employed in this research is sociological juridical research. This research is descriptive with qualitative data analysis. The results demonstrate that the drug addicts being involved in a criminal case during the investigation or prosecution stages may be admitted to the medical rehabilitation and social rehabilitation processes only after passing the assessment. The assessment will be conducted by an Integrated Assessment Team consisting of a Legal Team and a Doctor Team. The Integrated Assessment Team will determine whether or not a suspect or offender of drug abuse is only a drug addict or serves also as a drug dealer. The Medical Team will make some examination or tests on the drug level and severity of the addict. If the Integrated Assessment Team after the examinations decides that the addict may be admitted to the medical rehabilitation program, the suspect or the offender of drug abuse will be handed over to a rehabilitation institution. The coordination between the investigators or public prosecutors and the medical rehabilitation institutions will be established from the early stage of hand over, implementation, until the return of the addict to the investigator or public prosecutor. If the suspect or offender is under the rehabilitation program as an outpatient, the discretion to make the suspect or offender under the rehabilitation program present, lies on the institution that admits the suspect or offender into the program (the investigator or public prosecutor).
\end{abstract}

Keywords: assessment; medical rehabilitation; drug abuse 


\section{ABSTRAK}

Pasal 54 Undang-Undang Nomor 35 Tahun 2009 Tentang Narkotika mengatur bahwa pecandu narkotika dan korban penyalah guna narkotika wajib menjalani rehabilitasi medis dan sosial. Selanjutnya pasal 127 ayat (3) undang-undang tersebut menyatakan bahwa dalam hal penyalah guna dapat dibuktikan atau terbukti sebagai korban penyalahgunaan narkotika, penyalah guna tersebut wajib menjalani rehabilitasi medis dan rehabilitasi sosial. Pengaturan tersebut membuka peluang bagi orang yang sedang dalam proses hukum terkait kasus narkotika untuk mengajukan rehabilitasi medis dan rehabilitasi sosial. Dapat atau tidaknya menjalani proses rehabilitasi pada tahap penyidikan dan penuntutan akan tergantung kepada proses asesmen yang dilakukan. Proses asesmen ini berperan penting dalam menentukan rehabilitasi terhadap penyalah guna narkotika. Rumusan masalah yang akan dibahas, yaitu: 1) Bagaimanakah proses asesmen terhadap pecandu narkotika pada tahap penyidikan dan penuntutan, 2) Bagaimanakah koordinasi penyidik dan penuntut umum dengan lembaga rehabilitasi medis dan rehabilitasi sosial. Metode penelitian yang digunakan adalah penelitian yuridis sosiologis. Penelitian ini bersifat deskriptif dengan analisis data dilakukan secara kualitatif. Hasil penelitian menunjukkan bahwa terhadap penyalah guna narkotika yang menjalani proses hukum pada tahap penyidikan atau penuntutan dapat menjalani rehabilitasi medis dan rehabilitasi sosial setelah melalui proses asesmen. Proses asesmen dilaksanakan oleh Tim Asesmen Terpadu yang terdiri dari Tim Hukum dan Tim Dokter. Melalui Tim Asesmen Terpadu akan ditentukan apakah seorang tersangka atau terdakwa penyalah guna narkotika sebagai pengedar atau pecandu narkotika serta melalui Tim Medis akan diuji kandungan serta tingkat keparahan pengguna narkotika. Apabila berdasarkan pemeriksaan Tim Asesmen Terpadu diputuskan dapat menjalani rehabilitasi medis, maka tersangka atau terdakwa penyalah guna narkotika akan diserahkan ke lembaga rehabilitasi. Koordinasi antara penyidik atau penuntut umum dengan lembaga rehabilitasi medis dapat dilihat dari awal penyerahan, pelaksanaan, hingga penyerahan kembali kepada penyidik atau penuntut umum. Khusus untuk rehabilitasi yang dilaksanakan dengan rawat jalan, kewenangan menghadirkan tersangka atau terdakwa yang direhabilitasi ada pada lembaga yang menyerahkan (penyidik atau penuntut umum).

Kata kunci: asesmen; rehabilitasi medis; penyalahgunaan narkotika.

\section{PENDAHULUAN}

Beberapa tahun ini Indonesia berada dalam situasi darurat narkoba. Bahkan sampai pada akhir tahun 2017 pemerintah melalui Badan Narkotika Nasional (BNN) menyatakan perang terhadap narkoba. Bahkan dalam Press Release akhir tahun 2017 BNN mengemukakan tema "Kerja Bersama Perang Melawan Narkoba". Dari angka kasus narkoba, untuk periode Januari s/d Desember 2017 saja sebanyak 46.537 kasus narkoba telah berhasil diungkap. ${ }^{1}$ Angka ini menunjukkan bahwa masih tingginya kasus peredaran gelap narkoba di Indonesia.

Bahaya narkoba mengintai semua lini kehidupan, tidak terkecuali remaja dan anak-anak. Pada November 2017 diperoleh data sebanyak 5,1

1 Press Release Akhir Tahun 2017 Badan Narkotika Nasional Tanggal 27 Desember 2017

2 Pengguna narkoba pelajar mahasiswa, accessed mei 25, 2018 ,

Https://Nasional.Sindonews.Com/Read/1257498/15/ 40-Pengguna-Narkoba-Pelajar-Mahasiswa1510710950 juta orang pengguna narkoba dan 40 persennya adalah berasal dari kalangan pelajar dan mahasiswa. 2 Bahkan menurut data yang disampaikan oleh Komisi Perlindungan Anak Indonesia (KPAI) 5,9 juta anak di Indonesia menjadi pecandu narkoba. KPAI menyebutkan dari 2.218 kasus anak-anak terkait kesehatan dan NAPZA yang mereka tangani, 15, 69 persen kasus anak pecandu narkoba dan 8,1 persen anak sebagai pengedar narkoba ${ }^{3}$ Data tersebut menunjukkan sebuah fakta betapa masifnya peredaran dan penyalahgunaan narkoba di Indonesia.

Situasi dan kondisi tersebut diatas tentu saja menjadi sebuah keprihatinan yang pada akhirnya menuntut keseriusan dari semua pihak untuk mengatasi persoalan itu secara bersama-sama. Dari segi substansi perundang-undangan, dilakukan

3 5-9 juta anak Indonesia menjadi pecandu narkoba, accessed mei 25, 2018, Https://News.Okezone.Com/Read/2018/03/06/337/1 868702/5-9-Juta-Anak-Indonesia-Jadi-PecanduNarkoba 
penguatan upaya-upaya penegak hukum dalam pemberatasan penyalahgunaan narkotika melalui Undang-Undang Nomor 35 Tahun 2009 Tentang Narkotika. Terdapat perubahan paradigma yang sengaja diatur dalam undang-undang tersebut terkait dengan penanganan orang-orang yang terlibat dengan penyalahgunaan narkotika. Salah satu pergeseran paradigma tersebut adalah terkait dengan adanya rehabilitasi medis dan sosial terhadap orang-orang yang terlibat dengan penyalahgunaan narkotika.

Rehabilitasi medis merupakan suatu proses kegiatan pengobatan secara terpadu untuk membebaskan pecandu dari ketergantungan narkotika. ${ }^{4}$ Sedangkan rehabilitasi sosial adalah suatu proses kegiatan pemulihan secara terpadu, baik fisik, mental maupun sosial agar bekas pecandu narkotika dapat kembali melaksanakan fungsi sosial dalam kehidupan masyarakat. ${ }^{5}$

Penegasan mengenai adanya rehabilitasi medis dan sosial ini diatur dalam Pasal 54 UndangUndang Nomor 35 Tahun 2009 Tentang Narkotika yang mengatur bahwa "pecandu narkotika dan korban penyalah guna narkotika wajib menjalani rehabilitasi medis dan sosial'. Selanjutnya Pasal 127 ayat (3) undang-undang tersebut menyatakan bahwa dalam hal penyalah guna dapat dibuktikan atau terbukti sebagai korban penyalahgunaan Narkotika, penyalah guna tersebut wajib menjalani rehabilitasi medis dan rehabilitasi sosial.

Demikian juga halnya, dalam proses persidangan pidana, hakim wajib memperhatikan ketentuan mengenai rehabilitasi medis dan sosial sebagaimana diatur dalam Pasal 127 ayat (2) Undang-Undang Narkotika. Bahkan melalui Pasal 103 undang-undang tersebut, hakim dapat menjatuhkan putusan atau penetapan untuk menjalani rehabilitasi medis bagi pecandu narkotika.

Kewajiban menjalani rehabilitasi ini dipertegas melalui Pasal 3 ayat (1) Peraturan Kepala Badan Narkotika Nasional Nomor 11 Tahun 2014 tentang Tata Cara Penanganan Tersangka dan/atau Terdakwa Pecandu Narkotika dan Korban Penyalahgunaan Narkotika ke dalam Lembaga Rehabilitasi. Peraturan tersebut mengatur bahwa pecandu narkotika dan korban penyalahgunaan narkotika yang tanpa hak dan melawan hukum sebagai tersangka dan/atau terdakwa dalam

$4 \quad$ Pasal 1 Butir 16 Undang-Undang No.35 Tahun 2009 Tentang Narkotika (Republik Indonesia, 2009) penyalahgunaan narkotika yang sedang menjalani proses penyidikan, penuntutan, dan persidangan di pengadilan diberikan pengobatan, perawatan dan pemulihan dalam lembaga rehabilitasi. Hal ini membuka peluang bagi orang yang sedang dalam proses hukum terkait dengan kasus narkotika untuk mengajukan rehabilitasi medis dan sosial.

Meningkatnya kasus penyalahgunaan narkotika di Indonesia saat ini merupakan sebuah situasi dan kondisi yang mengkhawatirkan. Upaya mengatasi permasalahan kejahatan narkotika tidak cukup hanya dengan penggunaan sanksi pidananya saja tetapi juga perlu digunakan pendekatan lainnya. Terhadap pecandu narkotika misalnya, aspek kecanduan atau ketagihan dari narkotika tersebut perlu menggunakan pendekatan lain, yaitu rehabilitasi medis dan sosial. Rehabilitasi menjadi salah satu upaya depenalisasi dalam kasus penyalahgunaan narkotika, dimana tindakan ini mengurangi aspek penghukuman dalam hukum pidana. Di samping itu, rehabilitasi medis diyakini dapat menjadi salah satu cara untuk memutus mata rantai peredaran narkotika dengan menghilangkan aspek kecanduan bagi penggunanya.

Melalui Peraturan Bersama Ketua Mahkamah Agung Republik Indonesia, Menteri Hukum dan Hak Asasi Manusia Republik Indonesia, Menteri Kesehatan Republik Indonesia, Menteri Sosial Republik Indonesia, Jaksa Agung Republik Indonesia, Kepala Kepolisian Republik Indonesia, Kepala Badan Narkotika Nasional Republik Indonesia. No. : 01/PB/MA/III/2014, No. : 03 Tahun 2014, No. : 11 Tahun 2014, No. : 03 Tahun 2014, No.: PER-005/A/JA/03/2014, No. : 1 Tahun 2014, No.: PERBER/01/III/2014/BNN tentang Penanganan Pecandu Narkotika dan Korban Penyalahgunaan Narkotika ke dalam Lembaga Rehabilitasi mengatur bahwa pecandu narkoba tidak lagi bermuara pada sanksi pidana penjara melainkan bermuara di tempat rehabilitasi, karena sanksi bagi pecandu disepakati berupa rehabilitasi.

Berdasarkan Peraturan Bersama tersebut diatur mengenai proses asesmen yang harus dijalankan terlebih dahulu untuk menentukan dapat atau tidaknya tersangka atau terdakwa menjalani rehabilitasi. Menurut peraturan tersebut dibentuk Tim Asesmen Terpadu yang berkedudukan di tingkat pusat, tingkat propinsi, tingkat kabupaten/kota yang terdiri dari tim dokter dan tim

$5 \quad$ Pasal 1 Butir 17 Undang-undang No.35 Tahun 2009 Tentang Narkotika (Republik Indonesia, 2009) 
hukum yang bertugas melaksanakan analisis peran tersangka yang ditangkap atas permintaan penyidik. Tim tersebut kemudian melaksanakan analisis hukum, analisis medis dan analisis psikososial serta membuat rencana rehabilitasi yang memuat berapa lama rehabilitasi diperlukan.

Hasil asesmen tersebut sebagai kelengkapan berkas perkara yang berfungsi sebagai keterangan seperti visum et repertum. Hasil analisis akan memilah-milah peran tersangka sebagai penyalah guna, penyalah guna merangkap pengedar atau pengedar. Setelah melalui proses asesmen, para pecandu narkoba akan bermuara di pusat rehabilitasi.

Proses asesmen menempati posisi penting untuk dapat atau tidaknya bagi penyalah guna narkotika menjalankan rehabilitasi medis dan rehabilitasi sosial. Undang-undang memberikan kesempatan bagi setiap pecandu dan korban penyalah guna narkotika menjalani rehabilitasi. Rehabilitasi medis dan sosial diyakini sebagai sebuah upaya yang dapat memutus mata rantai peredaran narkotika melalui penanganan terhadap pecandu dan korban penyalah guna. Upaya ini tentu saja menuntut perlunya optimalisasi proses asesmen terhadap orang yang ditangkap dan dijadikan sebagai terdakwa dalam kasus narkotika. Sehingga dari hasil tersebut dapat diketahui dengan jelas bahwa seseorang yang ditangkap atau tertangkap tangan oleh penegak hukum merupakan pengedar, kurir, penyalah guna sekaligus pengedar, pecandu, atau korban penyalah guna narkotika.

Ditengah dukungan terhadap upaya rehabilitasi medis bagi pecandu dan korban penyalah guna narkotika yang dalam proses hukum, tentu saja keputusan untuk melakukan rehabilitasi medis dan sosial memerlukan pertimbangan yang matang, teliti, dan hati-hati. Persoalan tersebut, misalnya dapat diketahui dari data di Pengadilan Negeri Padang, dimana hasil penelitian menunjukkan bahwa dari 321 kasus narkotika yang ditangani dalam rentang waktu Januari sampai Oktober 2017, terdapat 5 kasus yang diputus oleh hakim disertai dengan rehabilitasi medis (Dikutip dari data Laporan Akhir Penelitian a.n Riki Afrizal Tahun 2017, Universitas Andalas, Padang). Hal ini tentu menimbulkan pertanyaan sejauh mana proses asesmen memiliki peran untuk menentukan bahwa seorang perlu direhabilitasi atau tidak.

\section{Rumusan Masalah}

Sehubungan dengan perlunya optimalisasi proses asesmen terhadap penyalah guna narkotika pada tahap penyidikan dan penuntutan dalam rangka efektivitas rehabilitasi medis dan sosial, maka dalam penelitian ini akan dibahas mengenai

1) Bagaimanakah proses asesmen terhadap pecandu narkotika pada tahap penyidikan dan penuntutan;

2) Bagaimana koordinasi Penyidik dan Penuntut Umum dengan Badan Narkotika Nasional dalam proses asesmen tersebut.

\section{Tujuan}

Adapun tujuan penelitian yang ingin dicapai sebagai sasaran dalam penulisan ini dapat terbagai 2 (dua), yakni tujuan umum dan tujuan khusus. Secara umum, penelitian ini bertujuan untuk mempelajari efektivitas upaya pencegahan dan pemberantasan tindak pidana penyalahgunaan narkotika melalui paradigma baru rehabilitasi medis dan sosial.

Secara khusus, tujuan penelitian dalam penulisan ini adalah untuk dapat menjawab permasalahan sesuai dengan yang dikemukakan di atas, yakni:

1. Untuk mempelajari proses asesmen terhadap pecandu narkotika pada tahap penyidikan dan penuntutan dalam rangka efektivitas rehabilitasi medis;

2. Untuk mempelajari bagaimanakah koordinasi penyidik dan penuntut umum dengan Badan Narkotika Nasional dalam proses asesmen.

\section{METODE PENELITIAN}

Dalam penelitian ini digunakan metode yuridis sosiologis. Penelitian dilakukan dengan melihat kenyataan di dalam prakteknya mengenai optimalisasi proses asesmen terhadap penyalah guna narkotika dalam rangka efektivitas rehabilitasi medis dan sosial bagi pecandu narkotika. Oleh karena penelitian ini merupakan penelitian implementatif dengan analisis deskriptif, maka pendekatan yang digunakan adalah pendekatan kualitatif. Data yang diperoleh dilapangan dipaparkan secara natural dan faktual berdasarkan kenyataan yang didapat didalam penelitian. Pengumpulan data dilakukan dengan cara wawancara dan studi dokumen. Wawancara 
dilakukan terhadap petugas Badan Narkotika Nasional Provinsi Sumatera Barat.

Wawancara yang digunakan untuk mengumpulkan data primer dari narasumber. Karena data yang diharapkan dari metode wawancara ini adalah data yang bersifat mendalam terkait dengan proses asesment dengan menggunakan pedoman wawancara bebas (unstructured interview guidance). Dalam hal ini peneliti hanya membuat daftar pertanyaan yang pokok-pokok dan dikembangkan saat wawancara berlangsung. Wawancara dilakukan terhadap Efri Nurdin, SKM staf bidang rehabilitasi Badan Narkotika Nasional Provinsi Sumatera Barat.

Studi dokumen menggunakan data sekunder yang terdiri dari bahan hukum primer, sekunder, dan tersier. Data sekunder merupakan data kepustakaan berdasarkan literatur buku, peraturan perundang-undangan terkait serta artikel yang ada. Secara rinci terbagi atas kategori 3 (tiga) bahan hukum yakni :

a. Bahan hukum primer, yaitu berupa Peraturan Perundang-undangan yang berlaku, yaitu ; Undang-Undang Nomor 35 Tahun 2009 Tentang Narkotika, Surat Edaran Mahkamah Agung RI Nomor 4 Tahun 2010 Tentang Penempatan Penyalahgunaan, Korban Penyalahgunaan, dan Pecandu Narkotika Kedalam Lembaga Rehabilitasi Medis dan Rehabilitasi Sosial, Peraturan Badan Narkotika Nasional Nomor 11 Tahun 2014 Tentang Tata Cara Penanganan Tersangka dan/atau Terdakwa Pecandu Narkotika dan Korban Penyalahgunaan Narkotika Kedalam Lembaga Rehabilitasi

b. Bahan hukum sekunder, yaitu bahan hukum yang diambil sebagian atau seluruhnya yang telah dikumpulkan dari berbagai sumber, seperti bahan bacaan atau buku-buku yang ditulis para ahli;

c. Bahan hukum tersier, yaitu bahan-bahan yang memberi petunjuk maupun penjelasan terhadap bahan hukum primer seperti kamuskamus hukum.

6 Sudarto, Kapita Selekta Hukum Pidana, Cet.4 (Bandung: PT Alumni, 2010), 36

\section{PEMBAHASAN}

\section{A. Proses asesmen terhadap pecandu narkotika pada tahap penyidikan dan tahap penuntutan dalam rangka efektivitas rehabilitasi medis.}

Narkotika memiliki arti yang sama dengan narcosis yang berarti membius. Kata narkotika tersebut berasal dari Yunani "narke" yang berarti terbius sehingga tidak bisa merasakan apa-apa. ${ }^{6}$

Mengenai narkotika, pencegahan serta pemberantasan tindak pidana penyalahgunaannya diatur melalui Undang-Undang Nomor 35 tahun 2009 Tentang Narkotika. Pasal 1 angka (1) undangundang tersebut menyebutkan bahwa narkotika adalah zat atau obat yang berasal dari tanaman atau bukan tanaman, baik sintetis maupun semisintetis, yang dapat menyebabkan penurunan atau perubahan kesadaran, hilangnya rasa, mengurangi sampai menghilangkan rasa nyeri, dan dapat menimbulkan ketergantungan, yang dibedakan kedalam golongan-golongan sebagaimana terlampir dalam undang-undang.

Adapun golongan dari narkotika tersebut terbagi kedalam golongan I yang terdiri dari 65 jenis yang hanya dapat digunakan untuk tujuan pengembangan ilmu pengetahuan dan tidak digunakan dalam terapi serta mempunyai potensi sangat tinggi mengakibatkan ketergantungan. Golongan II merupakan narkotika yang berkhasiat untuk pengobatan yang digunakan sebagai pilihan terakhir dan dapat digunakan dalam terapi serta tujuan pengembangan ilmu pengetahuan mempunyai potensi tinggi dan mengakibatkan ketergantungan. Narkotika golongan III berkhasiat untuk pengobatan yang digunakan dalam terapi dan tujuan pengembangan ilmu pengetahuan, mempunyai potensi ringan dan mengakibatkan ketergantungan.

Narkotika merupakan zat yang sangat berbahaya apabila disalahgunakan. Akibat secara langsung terhadap pengguna yang menyalahgunakan narkotika adalah ketergantungan secara psikis. Ketergantungan secara psikis ini menyebabkan pengguna tidak bisa lepas dari narkotika tersebut.

Ketergantungan psikis (psychological dependence) akibat penggunaan narkotika ialah timbulnya keadaan lupa pada si pemakai, sehingga 
ia dapat melepaskan diri dari suatu situasi konflik tanpa bisa lepas dari sebab kesulitan tersebut. Pemakai narkotika semakin tidak dapat menyesuaikan diri dengan masyarakat sehingga kesulitan yang dialaminya akan semakin besar dan kebutuhan terhadap narkotika akan semakin besar pula. Sedangkan ketergantungan fisik (physical dependence) terkait dengan penggunaan narkotika selama beberapa waktu menimbulkan berkurangnya kepekaan terhadap bahan tersebut. Tubuh menjadi terbiasa hingga sampai pada kekebalan. Hal ini semakin menjadi rumit dimana dosis penggunaannya akan semakin meningkat dan ketika penggunaannya dihentikan akan mengakibatkan kematian. $^{7}$

Salah satu upaya yang dilakukan dalam pencegahan peredaran dan penyalahgunaan narkotika melalui mekanisme hukum terutama hukum pidana adalah melalui perumusan laranganlarangan yang disertai dengan ancaman sanksi pidana yang tegas terhadap penyalah guna narkotika. Sanksi pidana terhadap kejahatan tersebut harus sedemikian rupa agar mampu menekan kejahatan ini dari sisi pelaku.

Ancaman sanksi pidana penjara terhadap tindak pidana narkotika minimal 2 (dua) tahun penjara dan maksimal 20 (dua puluh) tahun penjara. Pidana penjara seumur hidup atau pidana mati dapat dijatuhkan dengan syarat untuk jenis narkotika berbentuk tanaman beratnya melebihi 1 (satu) $\mathrm{kg}$ atau tidak boleh melebihi 5 (lima) batang pohon serta untuk narkotika bukan tanaman beratnya melebihi 5 (lima) gram. Selanjutnya ancaman pidana seumur hidup juga dapat dijatuhkan dalam hal memberikan narkotika untuk digunakan orang lain yang mengakibatkan matinya orang lain tersebut atau cacat permanen.

Dari segi pembaharuan hukum pidana dan sebagai bentuk penggunaan alternatif lain dalam mengatasi persoalan narkotika ini dikenal adanya rehabilitasi medis dan rehabilitasi sosial. Ketentuan pasal 127 ayat (2) Undang-Undang Nomor 35 Tahun 2009 Tentang Narkotika menyebutkan bahwa "dalam memutus perkara sebagaimana dimaksud pada ayat (1), hakim wajib memperhatikan ketentuan sebagaimana dimaksud dalam Pasal 54, Pasal 55, dan Pasal 103".

Sudarto, Kapita Selekta Hukum Pidana, Cet.4 (Bandung: PT Alumni, 2010), 39-40
Pasal 54 Undang-Undang Narkotika mengatur tentang kewajiban menjalani rehabilitasi bagi pecandu dan korban penyalah guna narkotika. Sedangkan pasal 55 mengatur tentang kewajiban orang tua atau wali dari pecandu narkotika yang belum cukup umur untuk melapor guna mendapatkan pengobatan dan perawatan melalui rehabilitasi. Selanjutnya, bagi pecandu yang sudah cukup umur wajib melaporkan diri atau dilaporkan keluarganya guna mendapatkan rehabilitasi tersebut.

Pasal 103 Undang-Undang Nomor 35 Tahun 2009 Tentang Narkotika mengatur bahwa hakim dapat memutus atau menetapkan pecandu narkotika untuk menjalani rehabilitasi medis dan rehabilitasi sosial. Pasal tersebut diatas memperlihatkan bahwa rehabilitasi medis dan rehabilitasi sosial merupakan salah satu putusan yang bisa diambil oleh hakim dalam perkara penyalahgunaan narkotika.

Di Pengadilan Negeri Padang, dari 321 perkara narkotika (Januari s/d Oktober 2017) terdapat 5 perkara narkotika yang dijatuhkan pidana yang disertai dengan rehabilitasi medis (Dihimpun dari data Sistem Informasi Penelusuran Perkara di Pengadilan Negeri Padang). Dari data tersebut diatas, terlihat bahwa jumlah perkara narkotika yang diputus oleh hakim untuk menjalani rehabilitasi medis masih tergolong sedikit jika dibandingkan dengan keseluruhan perkara narkotika yang diadili.

Dominannya perkara narkotika yang bermuara pada penggunaan sanksi pidana dapat dipahami sebagai salah satu upaya pemberantasan peradaran dan penyalahgunaan narkotika. Namun, bukan berarti merupakan satu-satunya upaya memutus ketergantungan terhadap narkotika tersebut.

Sanksi pidana akan terlihat menjadi tidak berguna kalau kita hubungkan dengan pemulihan terhadap ketergantungan dan efek narkotika tersebut pada orang yang menggunakannya.

Rehabilitasi medis dan rehabilitasi sosial merupakan suatu upaya yang tepat untuk mengatasi persoalan sebagaimana yang dijelaskan diatas. Bagaimanapun juga efek ketergantungan seseorang harus segera dikurangi, dicegah, dan dihentikan agar tidak sampai pada status kecanduan dan 
bahkan sampai pada kondisi yang fatal yaitu kematian. ${ }^{8}$

Rehabilitasi medis dan rehabilitasi sosial sudah bisa dimintakan terhadap orang yang tertangkap atau menjalani proses pemeriksaan dalam kasus narkotika pada tahap penyidikan di kepolisian atau penuntutan.

Untuk dapat menentukan seseorang yang dalam proses hukum karena kasus narkotika menjalani rehabilitasi medis ditentukan melalui suatu proses asesmen. Adapun persyaratan asesmen terhadap penyalah guna narkotika dalam proses hukum (compulsory treatment) sebagai berikut: ${ }^{9}$

1) Surat permohonan dari penyidik/jaksa penuntut umum untuk dilakukan pemeriksaan

2) Surat permohonan dari klien/wali/kuasa hukum, identitas permohonan dari tersangka, hubungan pemohon dengan tersangka, kronologis dan pokok permasalahan penangkapan tersangka

3) Fotokopi surat izin berencana bila pemohon adalah kuasa hukum tersangka dan surat kuasa dari keluarga

4) Pas foto tersangka

5) Fotokopi KTP tersangka, pemohon atau kuasa hukum

6) Fotokopi Kartu Keluarga pemohon dan tersangka

7) Fotokopi keanggotaan BPJS

8) Fotokopi surat penangkapan dan surat penahanan

9) Surat keterangan dari tempat rehabilitasi bila tersangka pernah atau sedang dalam proses rehabilitasi

10) Hasil tes urin dari Laboratorium BNN/Puslabfor Mabes Polri/instansi kesehatan pemerintah

11) Menandatangani surat pernyataan permohonan rehabilitasi tidak dipungut biaya

8 Efri Nurdin, Staf Bagian Rehabilitasi BNN Sumbar, wawancara pada tanggal 19 Oktober 2018 di Padang

9 Efri Nurdin, Staf Bagian Rehabilitasi BNN Sumbar, wawancara pada tanggal 19 Oktober 2018 di Padang dan tidak memberikan imbalan kepada tim BNN

12) Penyidik/penuntut umum bersedia menandatangani surat pernyataan akan melampirkan hasil asesmen dalam BAP.

Dalam melakukan asesmen terhadap pecandu narkotika sebagai tersangka penyalah guna narkotika dibentuk Tim Asesmen Terpadu. Tim Asesmen Terpadu ini terdiri dari:

a. Tim Dokter yang meliputi dokter dan psikolog

b. Tim Hukum, yang terdiri dari unsur Polri, BNN, Kejaksaan, dan Kemenkumham

Tim Asesmen Terpadu mempunyai kewenangan:

1) Atas permintaan penyidik untuk melakukan analisis peran seseorang yang ditangkap atau tertangkap tangan sebagai korban penyalahgunaan narkotika, pecandu narkotika, atau pengedar narkotika

2) Menentukan kriteria tingkat keparahan pengguna narkotika sesuai dengan jenis kandungan yang dikonsumsi, situasi, dan kondisi ketika ditangkap pada tempat kejadian perkara

3) Merekomendasikan rencana terapi dan rehabilitasi terhadap pecandu narkotika dan korban penyalahgunaan narkotika.

Tim hukum bertugas melakukan analisis tentang kaitan antara peredaran gelap narkotika, prekursor, dan penyalahgunaan narkotika dengan berkoordinasi bersama penyidik yang menangani perkara. Hasil analisis tim hukum pada proses asesmen ini berguna untuk menentukan bahwa yang bersangkutan tidak terlibat dengan peredaran gelap narkotika.

Melalui asesmen ini, atas permintaan penyidik, tim hukum dapat melakukan analisis terhadap peran seseorang yang ditangkap atau tertangkap tangan menggunakan narkotika sebagai pecandu atau sebagai pengedar. ${ }^{10}$ Apabila hasil asesmen menunjukkan bahwa yang bersangkutan

10 Ratna WP, Aspek Pidana Penyalahgunaan Narkotika: Rehabilitasi Versus Penjara (Menyoroti Pasal 127 Undang-Undang Nomor 35 Tahun 2009), (Yogyakarta: Legality, 2017), 93 
tidak terlibat peredaran gelap narkotika, maka akan memiliki kesempatan yang lebih besar untuk mendapatkan rehabilitasi.

Pemeriksaan pada proses asesmen ini sangat penting untuk menentukan seorang tersangka atau terdakwa merupakan pecandu narkotika dan korban penyalahgunaan narkotika, guna proses rehabilitasi. Namun, dalam banyak kasus pecandu juga terlibat sebagai pengedar atau kurir sehingga rehabilitasi medis dan sosial tidak mungkin diterapkan.

Rehabilitasi terhadap pecandu narkotika dilakukan dirumah sakit yang ditunjuk oleh menteri. Terhadap tersangka atau terdakwa yang berdasarkan keputusan Tim Asesmen Terpadu menjalani rehabilitasi medis, selanjutnya akan diserahkan kepada lembaga yang ditunjuk tersebut. Berdasarkan Peraturan Menteri Kesehatan Nomor 50 Tahun 2015 Tentang Petunjuk Teknis Pelaksanaan Wajib Lapor Dan Rehabilitasi Medis Bagi Pecandu, Penyalah guna, Dan Korban Penyalahgunaan Narkotika, menyebutkan prosedur penyerahan sebagai berikut:

\section{Penyerahan:}

a) Penyerahan dilakukan oleh penyidik atau penuntut umum didampingi oleh pihak keluarga dan pihak Badan Narkotika Nasional dengan melampirkan rekomendasi rencana terapi rehabilitasi dari Tim Asesmen Terpadu.

b) Penyerahan dilakukan pada jam kerja administratif fasilitas rehabilitasi medis yang ditunjuk.

c) Serah terima tersangka atau terdakwa di fasilitas rehabilitasi yang ditunjuk harus disertai dengan pemberian informed consent (yakni persetujuan setelah mendapat informasi dari pihak fasilitas rehabilitasi) dari tersangka atau terdakwa, disaksikan oleh penyidik atau penuntut umum dan pihak keluarga.

\section{Pelaksanaan:}

a) Rehabilitasi medis bagi tersangka atau terdakwa dilakukan dengan cara rawat inap atau rawat jalan sesuai dengan permintaan resmi tertulis pihak kepolisian, BNN/BNNP/BNNK (penyidik), atau kejaksaan (penuntut umum) yang didasarkan pada rekomendasi rencana terapi rehabilitasi dari Tim Asesmen Terpadu, untuk jangka waktu paling lama 3 (tiga) bulan.

b) Dalam hal tersangka atau terdakwa menjalani terapi rehabilitasi rawat inap, selama menjalani penitipan di fasilitas rehabilitasi medis, terdapat beberapa hal yang harus diperhatikan oleh pasien, yaitu:

1) wajib mengikuti program yang ditentukan oleh fasilitas rehabilitasi medis tersebut;

2) Tidak membawa alat komunikasi; dan

3) Komunikasi dengan keluarga / pihak lain harus melalui petugas kesehatan yang melakukan rehabilitasi.

c) Dalam hal tersangka atau terdakwa menjalani terapi rehabilitasi rawat jalan, kewenangan menghadirkan tersangka atau terdakwa untuk mengikuti proses rehabilitasi terletak pada penyidik atau penuntut umum (bergantung pada tingkat perkara).

d) Pihak fasilitas rehabilitasi medis memberikan informasi kepada pengadilan yang menetapkan 2 (dua) minggu sebelum masa rehabilitasi selesai.

e) Pasien yang telah selesai menjalani terapi rehabilitasi sebagaimana dimaksud dalam huruf $\mathrm{b}$ diserahkan kembali kepada pihak yang menitipkan tersangka atau terdakwa (penyidik atau penuntut umum) dengan menyerahkan resume akhir kegiatan terapi rehabilitasi.

Pengamanan dan pengawasan tersangka atau terdakwa yang ditempatkan di fasilitas rehabilitasi medis dilaksanakan oleh fasilitas rehabilitasi medis tersebut dan dapat berkoordinasi dengan pihak kepolisian.

Proses asesmen yang dilaksanakan terhadap seorang tersangka yang merupakan pecandu narkotika pada tahap penyidikan ataupun penuntutan, secara umum berakhir pada diberikannya rekomendasi untuk menjalani rehabilitasi medis dan sosial. Sepanjang terpenuhi persyaratan bahwa yang bersangkutan murni pengguna yang tidak terlibat dengan peredaran narkotika. Melalui analisis Tim Asesmen Terpadu dapat diketahui tingkat keparahan kecanduan seseorang terhadap narkotika, disamping keterlibatannya dalam penggunaan narkotika tersebut. 
Hal ini menunjukkan bahwa dari segi pelaksanaan asesmen tidak menjadi persoalan yang dapat menghambat terlaksananya proses rehabilitasi medis dan rehabilitasi sosial.

\section{B. Koordinasi Penyidik dan Penuntut Umum dengan Badan Narkotika Nasional Dalam Proses Asesmen}

Koordinasi antara penegak hukum dengan pihak terkait termasuk BNN dan lembaga lainnya dalam rangka pelaksanaan rehabilitasi sangat menentukan. Koordinasi terkait dengan upaya untuk rehabilitasi medis dan rehabilitasi sosial tersebut bisa dilihat pada saat proses asesmen dilakukan terhadap seorang pecandu atau korban penyalah guna narkotika yang menjadi tersangka.

Proses asesmen dilakukan oleh Tim Asesmen Terpadu yang terdiri dari tim hukum dan tim medis. Tim hukum yang terlibat dalam asesmen terpadu terdiri dari Badan Narkotika Nasional, Kepolisian, Kejaksaan, Perwakilan Kemenkumham, dan tim dokter/psikolog.

Tim Asesmen Terpadu dalam prakteknya yang koordinir oleh Badan Narkotika Nasional dapat melakukan analisis terhadap peran seseorang yang ditangkap atau tertangkap tangan sebagai korban penyalahgunaan narkotika atau pecandu narkotika berdasarkan permintaan penyidik atau penuntut umum. Melalui tim hukum, Tim Asesmen Terpadu akan ditentukan sejauhmana keterlibatan seseorang dalam penyalahgunaan narkotika. Hal ini akan berkaitan dengan fakta pada saat dilakukan penangkapan atau tertangkap tangan. Jumlah barang bukti narkotika yang didapat akan sangat menentukan dalam hal ini. Hasil penelitian Tim Hukum ini akan sangat berguna untuk menentukan sikap penyidik dalam proses penyelidikan dan penyidikan. Demikian juga terhadap proses asesmen yang dimintakan oleh Penuntut Umum terutama ketika memasuki proses peradilan. ${ }^{11}$

Setiap orang yang ditangkap atau tertangkap tangan menggunakan narkotika yang mengajukan proses asesmen untuk rehabilitasi medis sepanjang tidak memenuhi kriteria sebagai pengedar atau dengan jumlah kadar barang bukti berupa narkotika tidak melebihi batas yang ditentukan, maka penyidik berdasarkan permintaan yang

11 Efri Nurdin, Staf Bagian Rehabilitasi BNN Sumbar, wawancara pada tanggal 19 Oktober 2018 di Padang bersangkutan akan mengajukan dan melakukan pengurusan proses asesmen.

Setelah permohonan asesmen disampaikan, maka Tim Asesmen Terpadu yang terdiri dari Tim Hukum dan Tim Dokter akan melakukan akan melakukan analisis terhadap seseorang yang ditangkap dan/atau tertangkap tangan dalam peredaran dan penyalahgunaan narkotika. Kegiatan ini bertujuan agar pecandu dan/korban penyalahgunaan narkotika yang ditetapkan sebagai tersangka atau terdakwa dalam perkara tindak pidana narkotika selama dan setelah proses peradilan dapat ditempatkan kedalam lembaga rehabilitasi guna memperoleh pengobatan dan perawatan dalam rangka pemulihan ketergantungan terhadap narkotika. ${ }^{12}$

Koordinasi dalam proses asesmen ini dapat diartikan sebagai salah satu upaya bersama dari penegak hukum untuk menyelamatkan seseorang dari ketergantungan dan bahaya narkotika bagi dirinya. Dalam proses asesmen ini diperlukan pemahaman bersama dari Penyidik, Penuntut Umum, dan Badan Narkotika Nasional terkait dengan pentingnya rehabilitasi medis dan rehabilitasi sosial terhadap seseorang.

Rehabilitasi medis merupakan alternatif selain pendekatan hukum pidana terkait penyalah guna narkotika. Langkah ini menekankan kepada aspek pemulihan ketergantungan seseorang terhadap narkotika. Dengan pemahaman akan pentingnya keberadaan rehabilitasi medis sebagai salah satu terobosan dalam upaya mencegah ketergantungan terhadap narkotika, maka akan berpengaruh terhadap cara penyidik dalam memperlakukan seseorang yang sedang ditangani terkait perkara narkotika.

\section{KESIMPULAN}

Dari pembahasan yang telah diuraikan diatas dapat disimpulkan:

1) Terhadap penyalah guna narkotika yang menjalani proses hukum pada tahap penyidikan atau penuntutan atau setelah putusan pengadilan dapat menjalani rehabilitasi medis dan rehabilitasi sosial setelah melalui proses asesmen. Proses

12 Efri Nurdin, Staf Bagian Rehabilitasi BNN Sumbar, wawancara pada tanggal 19 Oktober 2018 di Padang 
asesmen dilaksanakan oleh Tim Asesmen Terpadu yang terdiri dari Tim Hukum dan Tim Dokter. Melalui Tim Asesmen Terpadu akan ditentukan apakah seorang tersangka atau terdakwa penyalah guna narkotika sebagai pengedar atau pecandu narkotika atau korban penyalah guna narkotika serta melalui Tim Medis akan diuji kandungan serta tingkat keparahan pengguna narkotika. Apabila berdasarkan pemeriksaan Tim Asesmen Terpadu diputuskan dapat menjalani rehabilitasi medis, maka tersangka atau terdakwa penyalah guna narkotika akan diserahkan ke lembaga rehabilitasi.

2) Koordinasi antara Penyidik, Penuntut Umum dengan Badan Narkotika Nasional terlihat pada saat Tim Asesmen Terpadu bekerja melakukan proses asesmen atau analisis terhadap peran seseorang dalam kasus narkotika yang sedang ditangani. Koordinasi diawali dengan penyampaian rencana rehabilitasi oleh Penyidik atau Penuntut Umum kepada Tim Asesmen Terpadu yang dikoordinir oleh Badan Narkotika Nasional. Selanjutnya Tim Asesmen Terpadu yang terdiri dari Tim Hukum dan Tim Medis akan melakukan analisis terhadap peran dari seseorang yang dimintakan rehabilitasi. Terakhir, Koordinasi antara Penyidik, Penuntut Umum, dengan Badan Narkotika Nasional adalah ketika seseorang disetujui dilakukan rehabilitasi medis, maka penyerahan dan pengawasan terhadap pelaksanaan rehabilitasi dilakukan oleh penegak hukum yang mengirim atau mengajukan rehabilitasi.

\section{SARAN}

1) Agar dalam penanganan perkara penyalahgunaan narkotika, terutama bagi pecandu dan korban penyalah guna narkotika, Penyidik dan Penuntut Umum bersama dengan badan narkotika nasional mengoptimalkan proses asesmen. Dengan optimalnya pelaksanaan asesmen, maka kemungkinan upaya rehabilitasi medis dan rehabilitasi sosial akan terlaksana.

2) Terlaksananya rehabilitasi medis, sebagai salah satu terobosan baru yang dimungkinkan oleh undang-undang narkotika dapat menjadi salah satu upaya selain penggunaan sanksi pidana dalam memutus ketergantungan dan kemungkinan meningkatnya peredaran narkotika.

\section{UCAPAN TERIMA KASIH}

Terima kasih sebesar-besarnya diucapkan kepada Mitra Bestari, Reviewer, Editor, dan Tim Pengelola Jurnal Penelitian Hukum De Jure atas bantuan dan kerjasamanya dalam penerbitan artikel ini. Selanjutnya juga diucapkan terimakasih kepada LPPM Universitas Andalas dan BNN Sumbar yang telah menerima dan mendanai penelitian ini serta semua pihak yang ikut membantu dalam penyelesaian artikel penelitian ini.

\section{DAFTAR KEPUSTAKAAN}

Https://Nasional.Sindonews.Com/Read/1257498/1 5/40-Pengguna-Narkoba-Pelajar-

Mahasiswa-

1510710950Https://News.Okezone.Com/Re $\mathrm{ad} / 2018 / 03 / 06 / 337 / 1868702 / 5-9-J u t a-A n a k-$ Indonesia-Jadi-Pecandu-Narkoba,

http://www.pn-padang.go.id

Peraturan kepala Badan Narkotika Nasional Nomor 11 Tahun 2014 Tentang Tata Cara Penanganan Tersangka dan/atau Terdakwa Pecandu Narkotika dan Korban Penyalahgunaan Narkotika Kedalam Lembaga Rehabilitasi

Press Release Akhir Tahun 2017 Badan Narkotika Nasional Tanggal 27 Desember 2017

Ratna WP, Aspek Pidana Penyalahgunaan Narkotika: Rehabilitasi Versus Penjara (Menyoroti Pasal 127 Undang-Undang Nomor 35 Tahun 2009), Yogyakarta: legality, 2017

Sudarto, Hukum dan Hukum Pidana, cet. Ke-5, Bandung : PT.Alumni, 2007

Sudarto, Kapita Selekta Hukum Pidana, Cet.4, Bandung : PT.Alumni, 2010.

Syaiful Bakhri, Kejahatan Narkotik Dan Psikotropika : Suatu Pendekatan Melalui Kebijakan Hukum Pidana, Jakarta : Gramata Publishing, 2012.

Undang-UndangNomor 35 Tahun 2009 Tentang Narkotika 